\title{
Tanzanian coastal forests - unique, threatened, and overlooked
}

\author{
Douglas Sheil
}

Tanzania's remaining fragments of coastal forests support rich biological communities, but these are extremely vulnerable to exploitation and land-use pressures because of their very limited size. Until recently little attention has been paid to these areas and and it is probable that all the most important forest areas have not yet even been recognized. Conservation measures are needed urgently and while these have been incorporated into the Tanzanian Forestry Action Plan, funding has not been identified.

\section{Introduction}

In coastal East Africa the once extensive moist forest cover has been reduced to tiny fragments. Those forests on the Tanzanian coast have received little attention until recently, when the recognition of their rich and unique composition generated a call for urgent action.

\section{Definitions and context}

The term 'coastal forest' has not received any entirely satisfactory floristic or geographical definition (see discussion in Hawthorne, 1984). The coastal forest vegetation is Zanzibar-Inhambane undifferentiated forest according to White's phytogeographic classification (1983a), the term 'undifferentiated' referring to the complexity of vegetation changes that can be found over short distances. Varying levels of disturbance further complicate analysis, because degraded forest and the subsequent thickets often preserve components of previous forest communities. A useful definition would be as follows:

* coastal forests lie fully within the monsoon climate of the Indian Ocean. (Rainfall bimodal, about 1000-2000 $\mathrm{mm}$ a year.)

* coastal forests are distinct from the lowland forests that surround mountainous areas (i.e. over $1000 \mathrm{~m}$ ) and which form a natural continuum with the sub-montane forests that occur at higher altitudes (see Figure 1).

* undisturbed coastal forest has a closed canopy in which few pioneer species are found; extensive clearance or opening up of the canopy leads to regeneration dominated by woodland species.

The coastal forests of Kenya are the best known, with the Shimba Hills, ArabukoSokoke Forest and the Tana River forest system having been fairly well documented, and with each attracting some conservation measures. Mozambique has some coastal forest (Collar and Stuart, 1985) but specific documentation is lacking. Information on Tanzania's coastal forests is very patchy, and probably not always accurate, but it is sufficient to argue strongly for protection.

\section{Tanzanian coastal forests}

The extent of evergreen and semi-evergreen forest in Tanzania is estimated to be less than 1 per cent by area (Mnzava, 1988), but comprises the richest biological communities in the country. The Tanzanian mountain forests have been widely recognized and are included on the list of 11 tropical areas world-wide that demand special attention due to their 'diversity, endemism and threatened status', drawn up by the Committee on Research Priorities in Tropical Biology (NAS, 1990). The much smaller coastal forests, however, have only 
recently been indicated as similarly requiring wider recognition (Lovett, 1985).

There has been no national survey of Tanzania's coastal forests and their entire area is probably no more than a few hundred square kilometres, with a large proportion of this being severely degraded. These habitat fragments constitute a forest archipelago along the entire coastal area, often associated with areas of raised ground (Figure 2). It is certain that further areas need to be positively identified.

The current status of many of these forests is not well known, although it is widely believed that most are under severe threat (Howell, 1981; Hawthorne, 1984; Lovett, 1985;
Rodgers et al., 1985; Sheil, 1990). A summary of relevant information is provided in Table 1 , but it should be recognized that much of these data are second-hand, out-of-date and unsubstantiated, and require extensive review by field and remote studies.

\section{Biogeographical significance}

The East African coastal forests have remarkably high levels of endemism and diversity. For example, of the 190 recorded forest tree species in the (low) coastal region, 92 are found nowhere else (White, 1983a).

The species richness of the coastal forests

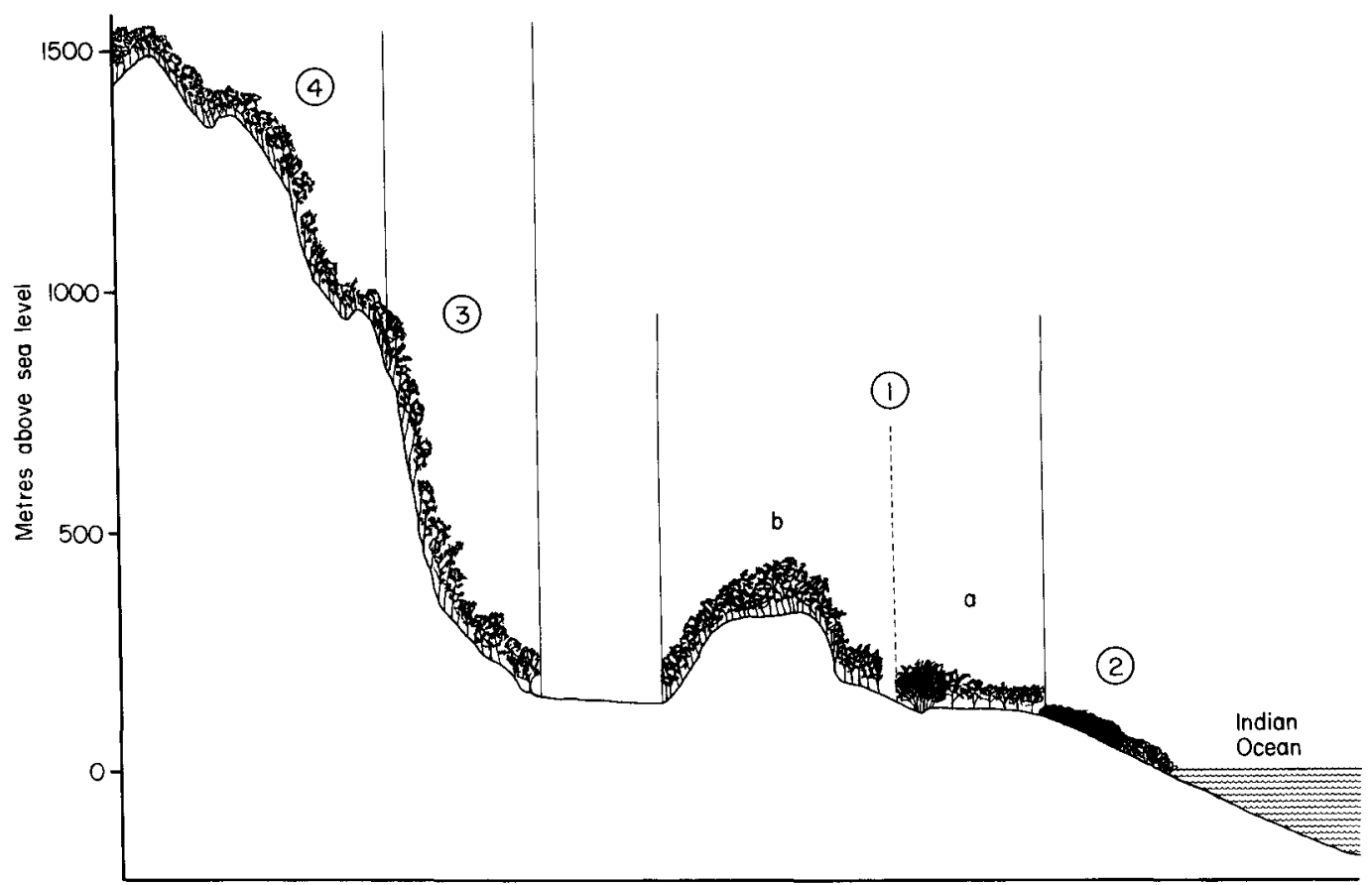

Figure 1. A schematic representation of the forests of coastal Tanzania.

Key

1. Coastal forests: (a) non-ancient, typically found on the landward side of mangrove forests and in river valleys; (b) ancient lineage, typically centred on areas of raised ground.

2. Mangrove forests, a distinct and widespread vegetation type along the Tanzanian coast.

3. Mountain-associated lowland forest. There is a gradual transition into the higher altitude forests, with which they form a continuum. These forests are climatically and hydrologically affected by their proximity to higher ground.

4. Submontane forests occur at altitudes above the lowland forests (the specific altitude varies, increasing with distance from the coast). 
may be due to the biogeographical factors that have also produced the rich East African montane communities (Rodgers and Homewood, 1982; White, 1983b; Hawthorne, 1984; Kingdon, 1990). Some of these are outlined below.

1. There has probably been forest cover in coastal areas of East Africa since the late Cretaceous (80 million years ago) (White, 1983a). The Indian Ocean has maintained an exceptionally stable oceanic climate for at least the last 40 million years (Hamilton, 1982). These factors have meant that the forests may have provided a refuge for species eliminated elsewhere by environmental change, and the continuity allowed for the steady evolution of specialized life forms and complex communities.

2. The East African forests are considered to have been isolated from other African forest complexes throughout most of their history (Faden, 1974; Hamilton, 1982), as indicated by the large numbers of species that are not found further to the west. The isolation of these forests has also operated at a smaller scale because they have been fragmented for much of their history. This has stimulated the independent evolution of individualistic communities in the context of localized geology, soil, climate and other factors.

3. Species elements from a number of origins can be found in the coastal forests. Species affinities range from those of Central Africa to Madagascar and the Indian Ocean. These affinities are not random; there are characteristics that distinguish northern coastal forests from those to the south (Hawthorne, 1984). An improved understanding of these species elements may provide insights into the climatic changes and habitat shifts that led to current distributions.

4. Past sea-level changes allow for the distinction of two categories of forest: (i) ancient lineage forests (centred on higher ground); (ii) non-ancient forests that do not pre-date past sea-level rises.

The non-ancient forests include riverine forests and those that occur as a succession from mangrove forest. These younger forests tend not to be as rich in endemics or species generally, but can be significant as habitat bridges and as remnants of previously more extensive forest systems. The floristically poor Jozani Forest in Zanzibar, for example, is the main site of the endemic Zanzibar colobus monkey Colobus kirkii (Robins, 1976).

The ancient coastal forests are in many ways

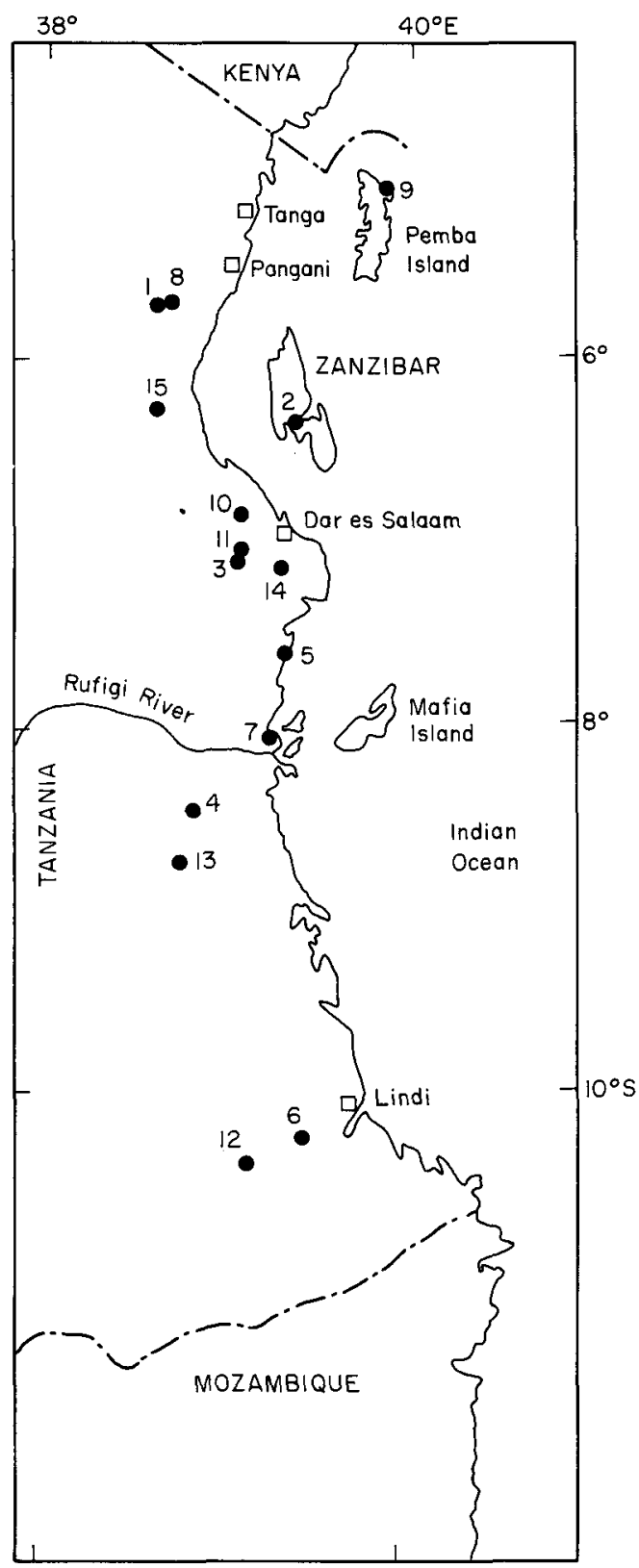

Figure 2. Known coastal forest areas in Tanzania (see Table 1) (drawn by Gordon Otieno). 
a subset of the lower montane forest systems. The distinction between low montane communities and ancient coastal forests is in many respects artificial as demonstrated by overlap in elements of their rich flora and fauna. They share many restricted species: examples include the Zanzibar bushbaby Galago zanzibaricus, the black-and-rufous elephant-shrew Ryhnchocyon petersi (Stuart, 1990), the centipede-eating snake Aparallactus werneri (Howell, pers comm.), numerous rare bird species (Collar and Stuart, 1985) and many forest plants. What makes these coastal forests particularly remarkable is not only the possession of many regional forest endemics, but the fact that each forest often contains significant numbers of locality-specific endemics.

\section{Kirengoma Forest - a case study}

Kirengoma Forest on the Matumbi Massif is an ancient coastal forest. Jonathan Kingdon predicted the existence and value of this forest, providing clear directions that enabled the author to locate the site in 1989 and initiate a preliminary survey (Kingdon, 1989).

The area is a patchwork of primary and secondary vegetation and shows evidence of some disturbance in virtually all areas. Landforms are varied, creating a diversity of physical environments. Springs provide dry season water, which attracts a significant number of elephants from the Selous Game Reserve to the west.

Bird life includes five species listed in the ICBP/IUCN Red Data Book (Collar and Stuart, 1985): southern banded snake eagle Circaetus fasciolatus, Uluguru violet-backed sunbird Anthreptes neglectus, tiny greenbul Phyllastrephus debilis, Kretschmer's longbill Macrosphenus kretschmeri and chestnut-fronted helmet shrike Prionops scopifrons. A possible new subspecies of Cnemaspis gecko was recorded, as well as new localities for the recently discovered fruit bat Myonycteris relicta and an as yet undescribed frog Stephopaede sp.

The majority of the arthropod collection remains to be identified, but for millipedes (Diplodia) findings have been remarkable, including seven new genera among many new species.

One early find for the botanical collection was the most southerly known site for an African violet. We found two small patches of Saintpaulia ionantha (the first-described species of the genus), which is currently only known from the Uzungwa Mountains and from a few remaining plants near the site of its original discovery in Tanga region to the north. Examination of the collections continues and several plant specimens remain unidentified as possibly new species. It was notable that over 90 per cent of the plant species we collected had one or more traditional uses, mostly as herbal remedies, an exceptional figure by African standards.

A collection of nitrogen-fixing leguminous plant species and their rhizobia was made. These are now being evaluated towards the development of sustainable agroforestry systems, so demonstrating another aspect of the forest as a genetic resource.

\section{Exploitation and damage}

Kirengoma Forest lies mostly within the Kirengoma Forest Reserve, although there is some debate about the actual boundaries (see below). There are examples of fresh settlement within the reserve and such incursion seems likely to continue. Local uses of the forest include the harvesting of medicinal plants, building poles, fruits, tubers, honey and mushrooms, but none of these practices appear unsustainable at present. Hunting is largely confined to crop protection measures at the forest edge. Economic influences are illustrated by the escalating collection of the currently abundant Bells' hinged tortoise Kinixys belliana within the reserve in response to a lucrative trade, which is almost certainly unsustainable.

There has been intense cutting of the best mahogany Khaya nyasica trees from the accessible riverine forest areas. The pit-sawers come from other regions, with the logging providing little gain or employment to local people who actively resent this exploitation of 
'their' forest. The actual practices employed are exceedingly wasteful; the timber trees are massive and bring down much other vegetation. Trees often fall in inaccessible places and are not processed further. If the timber is not prime quality (due to defects not visible prior to cutting) or splits on felling, then most or all of the tree is rejected. Much of the felling is unlicensed and if a tree felled illegally is discovered by an official from the Forestry Division, it is marked so that it cannot be used. This rarely happens and does not seem to deter further felling. One result of this rapid and unsustainable exploitation is that the canopy in most of the richest forest in the valley bottoms has been lost. Logging will undoubtedly continue unless tighter management is introduced, without which the future for light-sensitive species, such as the African violet, will remain bleak.

\section{Past destruction: future threats}

Many of the coastal forests lie within forest reserves administered by the Forest and Beekeeping Division of the Ministry of Lands,

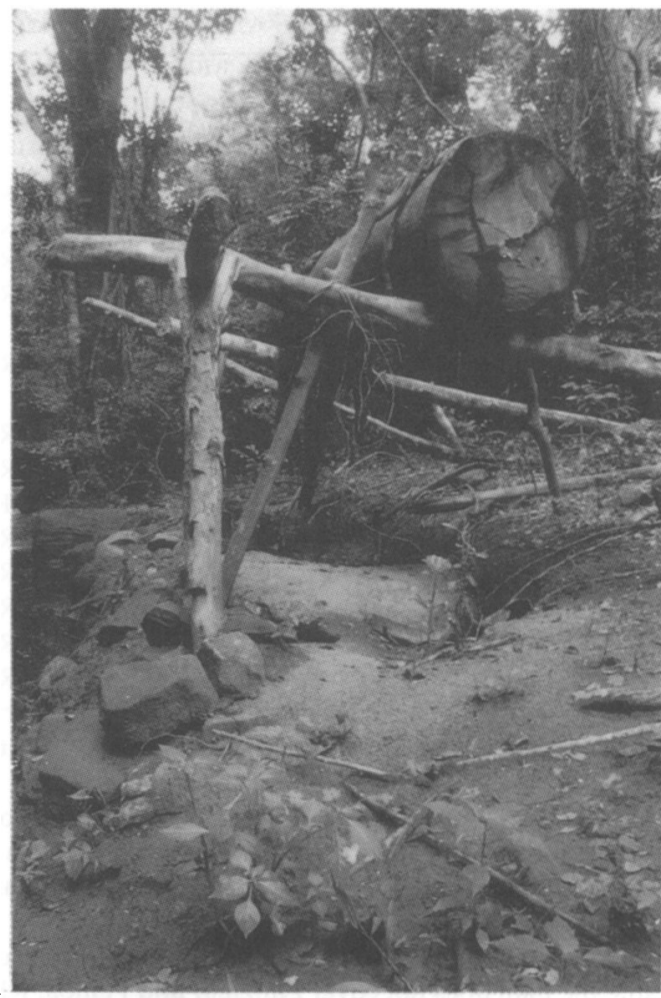

Pitsawing site, Kirengoma Forest, with Impatiens wallariana in foreground ( $J$. Webb).

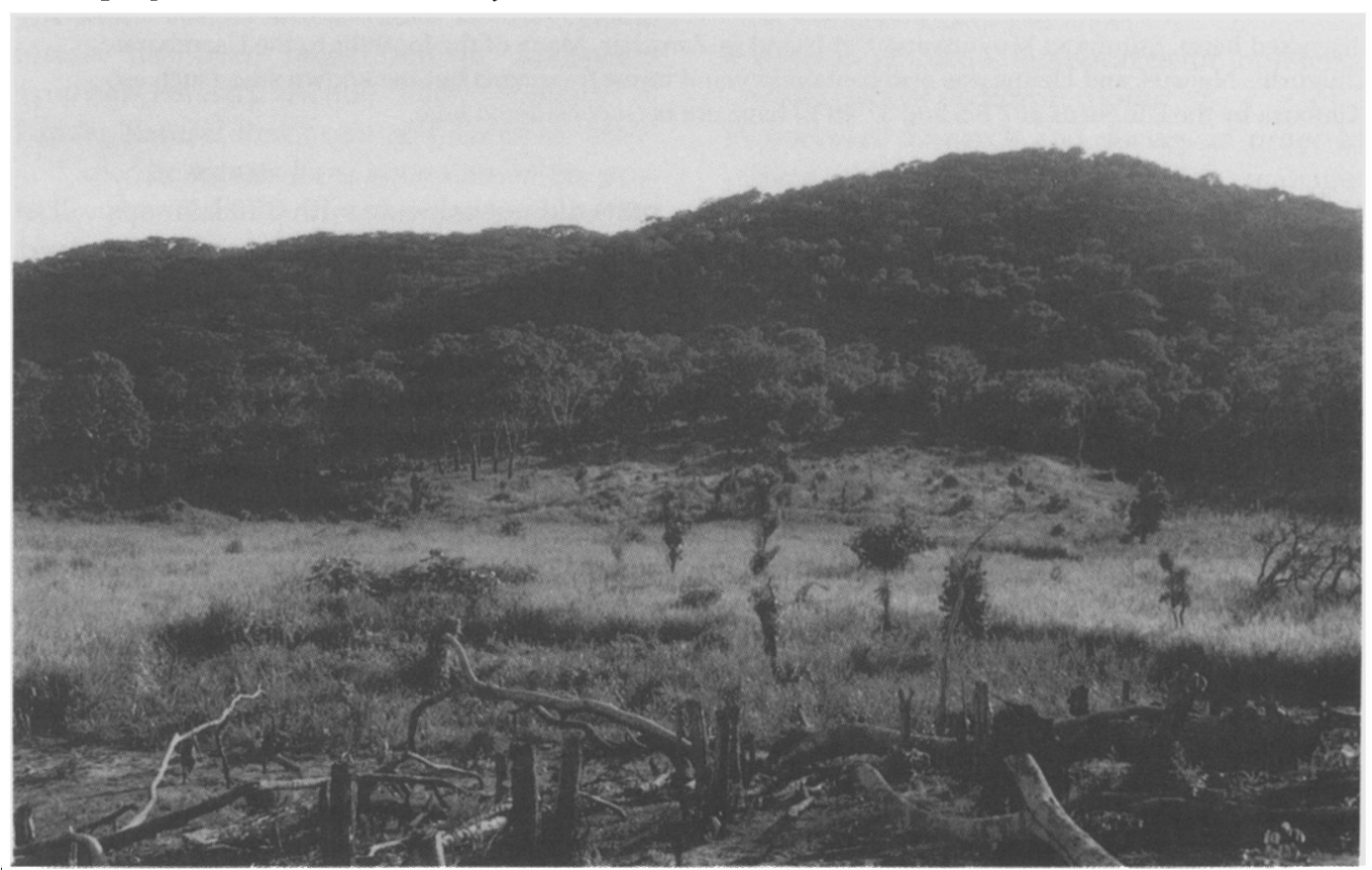

Kirengoma Forest Reserve edge showing recent cutting for conversion to agriculture $(J$. Webb). 
Table 1. A summary of information on known Tanazanian coastal forests

\begin{tabular}{|c|c|c|c|c|c|c|}
\hline \multicolumn{2}{|c|}{ Forest } & \multirow{2}{*}{$\frac{\begin{array}{l}\text { Area } \\
(\mathrm{sq} \mathrm{km})\end{array}}{7 ?}$} & \multirow{2}{*}{$\frac{\text { Age }^{1}}{*}$} & \multirow{2}{*}{$\begin{array}{l}\begin{array}{l}\text { Legal } \\
\text { status }^{2}\end{array} \\
\text { FR }\end{array}$} & \multirow{2}{*}{$\begin{array}{l}\text { Threats }^{3} \\
\mathrm{E}, \mathrm{F} ?\end{array}$} & \multirow[t]{2}{*}{ TFAP $^{4}$} \\
\hline 1. & Genda Genda & & & & & \\
\hline 2 & Jozani/Mapopwe & $2-5$ & & FR & $\mathbf{E}$ & \\
\hline 3. & Kasimzumbwi & $6-12$ & $*$ & $\mathrm{FR}$ & $\mathrm{F}$ & * \\
\hline 4. & Kirengoma & $15-25$ & * & FR? & $\mathrm{L}, \mathrm{E}, \mathrm{C}$ & \\
\hline 5. & Kisiju & 2 & & - & & \\
\hline 6. & Litipo & $10 ?$ & $*$ & FR & $?$ & \\
\hline 7. & Mchungo & 2 & & $?$ & & \\
\hline 8. & Msumbugwe & $10-15$ & $*$ & FR & & * \\
\hline & Ngezi & $15 ?$ & & FR & $\mathrm{E}$ & \\
\hline 10. & Pande & $8-10$ & $*$ & GR & $\mathrm{C}, \mathrm{F}$ & \\
\hline 11. & Pugu & $8-10$ & * & FR & $\mathrm{M}, \mathrm{F}$ & * \\
\hline 12. & Rondo $^{5}$ & $?-18 ?$ & $*$ & FR & $\mathrm{C}$ & * \\
\hline 13. & Tong'omba & $10-20$ & $*$ & FR & $\mathbf{L}$ & \\
\hline 14. & Vikindu $^{5}$ & $5-10$ & *? & FR & $C, F$ & \\
\hline 15. & Zaraninge & $19-22$ & $*$ & FR & $\mathrm{L}, \mathrm{E}$ & $*$ \\
\hline
\end{tabular}

Sources: Various, see references and acknowledgments.

Key

'Under 'Age' those forests with an * are considered to pre-date past sea-level changes.

${ }^{2} \mathrm{FR}$ means that the majority of the forest lies within a forest reserve. GR, game reserve.

${ }^{3}$ Threats: L, logging; E, encroachment; C, charcoal manufacture; M, mineral extraction; F, fire following disturbance.

* TFAP: Forests with an * are specifically earmarked for protection by the Tanzanian Forestry Action Plan

Note the plan does not cover Zanzibar and Pemba, which has its own sectorial review.

${ }^{5}$ The majority of the area quoted is probably plantation.

Note. There are probably other forests; there are references to: the Kichi Hills and the nearby portions of the

Selous Game Reserve but little information exists (it is likely that they are a drier vegetation type than that discussed here); Muungwi Muyuni and Uzi Island in Zanzibar. Many of the foothills to the Usambaras, Ulugurus, Ngurus, and Uzungwas also contain lowland forest fragments but the known sites (such as Kimboza by the Ulugurus at $7^{\circ} 8^{\prime} \mathrm{S}$ and $37^{\circ} 48^{\prime} \mathrm{E}$ ) have not been considered here.

Natural Resources and Tourism. The majority of the forests under discussion are already fully protected catchment forests from which most or all (depending on the region) significant extractions are illegal, the exception being the more southerly forests, such as Kirengoma, where some licensed felling is still allowed. The management of all these areas has been a very low priority over the years and regulations are rarely enforced. A frequent problem appears to be that the reserves are not clearly demarcated; encroachers always seem able to claim that the reserve is elsewhere. Indeed this problem of boundaries extends to higher management levels: in the Kirengoma Reserve it was found that the area that villagers and local officials believed to be reserved (indeed the best forest for the most part) did not coincide with official maps.

There has been a rapid increase in land prospecting and clearance following the abandonment of the Village Development Programme (Ujamaa). By night the glow of clearance fires was visible all around the Matumbi area. This expansion into relatively fertile forest sites, coupled with a continuing demand for timber, charcoal and raw materials, has put the future of virtually all the forests at risk (see Table 1).

All heavy disturbance results in the introduction of secondary vegetation into any remaining forest. This not only diminishes the biological value of the forest, but also introduces the risk of fires and further damage. Protection from fire will, however, allow the regrowth of forest, as is now apparent in parts 
of Zaraninge, where woodland is giving way to young forest regrowth.

Threats to many species remain acute, with larger species of animals being particularly vulnerable. Rodgers (1981) reported on the extinction of the black-and-white colobus Colobus angolensis in many coastal areas.

Not all threats are directly anthropogenic in origin. In Zaraninge forest, the eastern side is notable for the large number of standing and fallen dead trees, resulting in a broken canopy and dense patches of impenetrable regeneration. This mortality is not restricted to a particular species and trees of all age classes are affected. Most of the fallen trees are, however, large specimens. After discussion with local people it was apparent that this was due to the severe drought of 1973-1974 and a cyclone following 3 years later (Sheil, 1990). The level of destruction affecting one-third of the forest bears witness to the vulnerability of the forest to natural events, particularly when already restricted in size.

\section{Protection}

The high conservation value of the coastal forests has been recognized in Tanzania's Tropical Forestry Action Plan (Ministry of Lands, Natural Resources and Tourism, 1989) and specific forests have been named for protection (see Table 1). However, steps to implement this plan are yet to be taken. There is also a need to bring currently unrecognized areas, such as Kirengoma Forest, under protective control.

The enforcement of current regulations is inadequate, with lack of available resources being a key issue. Change of status of all these forest reserves to 'forest nature reserve' will not in itself improve the situation because at present such management designations have no legal basis in Tanzania. In response to pressure from the Wildlife Conservation Society of Tanzania, the severely exploited Pande Forest to the North of Dar es Salaam has been designated as a game reserve (WCST, 1991). It is to be hoped that attention to this issue will lead to a new form of legislative status for forest parks as is currently being formulated in Uganda (Tabor et al., 1990). Success will ultimately depend on attracting the necessary resources to instigate a full and comprehensive evaluation and conservation programme.

\section{Needs}

It is clear that the small size of coastal forests when compared with their remarkable biodiversity and endemism makes them priority targets for conservation. Stuart (1990) states the need to survey the coastal forests to select and establish strictly protected areas. The Wildlife Conservation Society of Tanzania is seeking to implement such a programme but has limited funds at its disposal. The World Wide Fund for Nature is currently reviewing its potential for collaboration on such a project, and has even considered which forests might of necessity be 'given up' in order to focus rapidly on those forests where almost pristine areas still remain. It remains to be seen whether or not these forests, considered almost insignificant until now, will attract the required funding.

Key areas for action will be:

* generating adequate resources for long-term management and protection;

* continued research and survey in order to form priorities for conservation management;

* gaining a higher conservation status for these forests, which can be legally enforced;

* clearer demarcation of reserve boundaries;

* consultation and consent of local communities to ongoing management strategies and their full involvement at all levels of implementation and review;

* involving local people in implementing management strategies;

* examining the potential for the sustainable extraction of non-timber products;

* designating adequate external 'buffer zones' to supply the needs of local communities for uel, poles and and other forest products;

* generating more awareness, locally and more widely, of the issues involved in forest conservation. 
Tanzania is actively increasing its potential to manage forests for non-timber benefits. It is to be hoped that the challenges posed by a coastal forest conservation scheme can be met by these changes and that as much assistance as possible will be provided to this end. Such institutional initiatives are crucial to the viability of tropical forest conservation generally.

\section{Acknowledgments}

I would like to acknowledge the field support provided by Frontier-Tanzania, a joint initiative of the Society for Environmental Exploration and the University of Dar es Salaam. I am indebted to Dr Kim Howell (Department of Zoology, University of Dar es Salaam [UDSM]), Kaj Vollessen (Royal Botanic Gardens, Kew), Jon Lovett (Missouri Botanic Garden and Department of Botany, [UDSM]), the Wildlife Conservation Society of Tanzania, and all expedition members with Frontier-Tanzania, for support with field work and discussion. I would also like to thank all the Tanzanian authorities who gave assistance, especially the Chama Cha Mapinduzi (CCM) of Sadani and Mbwara. I would like to thank Dr Alan Hamilton and Richard Barnwell (WWF), Alex Dickinson and Neil Burgess for providing additional information.

\section{References}

Collar, N.J. and Stuart, S.N. 1985. Threatened Birds of Africa and Related Islands: The ICBP/IUCN Red Data Book, Part 1. IUCN, Cambridge.

Faden, R.B. 1974. East African coastal-West African rain forest disjunctions. In East African Vegetation (eds E. M. Lind and M. E. S. Morrison), pp. 202203. Longman, London.

Hamilton, A.C. 1982. Environmental History of East Africa. A Study of the Quaternary. Academic Press, London.

Hawthorne, W.J. 1984. Biogeographic and Ecological Patterns in the Coastal Forests of Kenya and Tanzania. Ph.D Thesis, University of Oxford.

Howell, K.M. 1981. Pugu Forest Reserve: biological values and development. African Journal of Ecology, 19, 1-6.

Kingdon, J. 1989. Frontier Tanzania Expedition 1989-1994: Matumbi Interim Report. The Society for Environmental Exploration, London. Unpubl. Kingdon, J. 1990. Island Africa. Collins, London.

Lovett, J.C. 1985. An Overview of the Moist Forests of Tanzania. Tanzania National Scientific Research Council Research Monographs. Unpubl.

Ministry of Lands, Natural Resources and Tourism. 1989. Tanzania Forestry Action Plan 1990/912007/08. Dar es Salaam.

Mnzava, E.M. 1988. The environmental dilemma in Tanzania: options and strategies. Paper presented at Tanzania/DANIDA seminar on environment, September 1988. Forest Division, Dar es Salaam.

NAS (National Academy of Sciences). 1972. Research Priorities in Tropical Biology. Committee on Research Priorities in Tropical Biology, NAS, Washington, DC. 388 pp.

Robins, R.J. 1976. The composition of the Josani Forest, Zanzibar. Botanical Journal of the Linnean Society, 72, 223-234

Rodgers, W.A. 1981. The distribution and conservation status of colobus monkeys in Tanzania. Primates, 22(1), $33-45$

Rodgers, W.A. and Homewood, K.M. 1982. Species richness and endemism in the Usambara mountain forests, Tanzania. Biological Journal of the Linnean Society, 18, 197-242

Sheil, R.D. 1990. Preliminary Results of Biological Surveys in Zaraninge (Kiono) and Kirengoma (Matumbi Hills) Coastal Forests, Tanzania: January to March 1990. The Society for Environmental Exploration, London. Unpubl.

Stuart, S.N. 1990. The Threats to Biodiversity and Genetic Diversity in Tanzania. Paper presented at the Tanzania National Conservation Workshop, Dodoma, 12-17 November 1990.

Tabor, G.M., Johns, A.D., and Kasenene, J.M. 1990. Deciding the future of Uganda's tropical forests. Oryx, 24, 208-214.

WCST (Wildlife Conservation Society of Tanzania), 1991. Pande Forest. Miombo (WCST Newsletter), 6, 19.

White, F. 1983a. Vegetation Map of Africa-A Descriptive Memoir to Accompany the UNESCO/AETFAT/UNSO Vegetation Map of Africa. UNESCO, Paris.

White, F. 1983b. Long distance dispersal, overland migration and extinction in the shaping of tropical African floras. Bothalia, 14, 395.

D. Sheil, Dept of Plant Sciences, University of Oxford, South Parks Road, Oxford OX1 3RB, UK. 